Uralic studies, languages, and researchers

Edited by Sándor Szeverényi 
Studia uralo-altaica 54

Redigunt:

Katalin Sipőcz

András Róna-Tas

István Zimonyi 
Uralic studies, languages, and researchers

Proceedings of the $5^{\text {th }}$ Mikola Conference 19-20, September 2019

Edited by Sándor Szeverényi

Szeged, 2021 
(C) University of Szeged,

Department of Altaic Studies,

Department of Finno-Ugrian Philology

All rights reserved. No part of this book may be reproduced, stored in a retrieval system, or transmitted in any form or by other means, electronic, mechanical, photocopying, recording or otherwise, without the prior permission in writing of the author or the publisher.

Printed in 2021.

Printed by: Innovariant Ltd., H-6750 Algyő, Ipartelep 4.

ISBN 978-963-306-803-8 (printed)

ISBN 978-963-306-804-5 (pdf)

ISSN 0133-4239 (Print)

ISSN 2677-1268 (Online) 
Table of contents

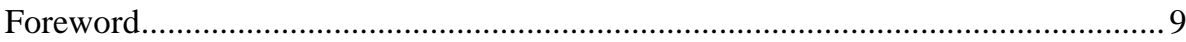

Sándor Szeverényi

Notes on Nicolaes Witsen and his Noord en Oost Tartarye. 11 Rogier Blokland

Undiscovered treasures: From the field research archive to the digital database......27 Beáta Wagner-Nagy, Chris Lasse Däbritz, and Timm Lehmberg

On the language use of the first Finnish medical text 45

Meri Juhos

Sajnovics, the responsible fieldworker 55

Sándor Szeverényi

The life and work of the Saami theologian and linguist: Anders Porsanger 71

Ivett Kelemen

The use and semantics of the Northern Mansi diminutive -riś $r \partial s$ ś 81

Bernadett Bíró

The event of "giving" and "getting" in Siberian Uralic languages 99

Katalin Sipöcz

A word-formational approach to neologisms in modern Northern Mansi

Susanna Virtanen

Word and stem repetitions in the heroic epic songs collected by Antal Reguly ..... 131 Mária Sipos

The use of body part terms in expressing emotions in Udmurt 149

Rebeka Kubitsch

The characteristics of responses given to compliments in Udmurt 173

Zoltán Németh

On some Chuvash-Mari shared lexemes and Agyagási's "Late Gorodets" hypothesis .. 185 Christopher Culver 
“Сувениры Севера" Minority identity and discourse. Representation of indigenous minorities of Northern Russia in the digital media. The case of Dudinka ........... 201 Zsuzsa Várnai and Ágnes Hámori

Reconsidering the Nganasan vowel system 229 László Fejes

New aspects in the study of Mari, Udmurt, and Komi-Permyak: The Typological Database of the Volga Area Finno-Ugric Languages 255 Erika Asztalos, Nikolett F. Gulyás, Laura Horváth, and Bogáta Timár Ethnosyntax in Siberian Uralic Languages (a project report) 275 Bernadett Bíró, Katalin Sipöcz, and Sándor Szeverényi 


\title{
On the language use of the first Finnish medical text
}

\author{
Meri Juhos \\ University of Debrecen
}

\section{Introduction}

The present paper analyzes the language use of the first Finnish medical text, its sound representations, spelling rules, and foreign origin words in the corpus. It was in 1788 that the first written work of medical subject matter was published in Finnish titled Maan-Miehen Huone- ja Koti-Aptheeki [Farmers' home remedies]. The author of this book was Kristfrid Ganander (1741-1790), who made field trips to collect popular medicine practices among the Finnish people. He complemented these with medical formulae earlier published in other languages in medicine books, translating them into Finnish. He also included an index in his book.

Ganander graduated as a theologian and served as a chaplain in Rantsila, near Oulu, from 1755 to his death. He is best known for the first Finnish comprehensive dictionary titled Nytt Finskt Lexicon [New Finnish Encyclopaedia] (1787), and for Mythologia Fennica (1789). He published eleven works altogether on a variety of subject matters, including collections of folk poetry and folk tales, glossaries, medical writings, and also poems of his own. He also collected riddles and proverbs that he published in the volume titled Aenigmata Fennica, Suomalaiset Arwotuxet Wastauksen kansa [Finnish riddles with answers] in 1783. This book contained 337 riddles with answers and was the first of its kind. Although most of Ganander's work is in the humanities, some of his writings cover topics of medical nature, including Maan-Miehen Huone- ja Koti-Aptheeki and Eläinden Tauti-Kirja [Farm animal diseases], the latter of which is about the diseases of farm animals and their treatment (for more about Ganander's life and work, see Gustaffson 1995: 203-219; Häkkinen 1995: 161-180; Pentikäinen 1995a: 133-160).

To understand the importance of the collection of formulae, it is important to know a little about the medical science of the time.

\section{Contemporary medical science}

In 18th century Finland, medical treatment was the privilege of a few. Although the 
Royal Academy of Turku, founded in 1640, provided an opportunity for the training of medical doctors, this did not mean at all that everybody in need of medical care received sufficient care. The country was divided into eight districts that all had a doctor of its own, and if there was no licensed doctor available, priests and folk healers provided treatment for sick people. People living far from big cities and working in agriculture could not afford to visit doctors.

It is not very surprising, given these circumstances, that the mortality rate of Finland was particularly high compared to neighboring countries. The main reasons for this were widespread poverty, the lack of basic hygiene, and the absence of doctors available at a reasonable distance. There were outbreaks of epidemics that could have been prevented by following basic rules of hygiene, for example, tuberculosis, dysentery, typhoid fever, pneumonia, pox, smallpox, chickenpox and rubeola (Forsius 2005: 81-99; Haarala 1999; Harjula 2007: 16; Ignatius 2000: 508-510).

The appearance of pharmacies in Finland sometime in the 18th century had a positive effect on this situation by providing ingredients not available at home or imported from abroad (Forsius 1995: 36-38).

During his field trips, Ganander became aware of the lack of health care and observed a number of practices used by folk healers. By publishing the descriptions of popular medicine practices he collected, his intention was to provide simple farmers living far away from doctors with a book that was easy to understand and that described formulae using local, easily accessible ingredients.

\section{The structure of the book}

Maan-Miehen Huone- ja Koti-Aptheeki contains 101 formulae that describe the preparation, dosage, and availability of ingredients of the given medicine in great detail. The intended audience was the community of Finnish-speaking farmers, so it was evident that the book had to be written in Finnish. However, the scientific and academic language of the time, including medical language, was dominated by Latin and Swedish, which meant that a number of phrases did not have Finnish equivalents, and some of the ingredients were put down by Ganander during his field trips in another language (primarily Swedish). The translation and simplification of the earlier Swedish formulae was probably not an easy task either, because they had to be understandable and still unambiguous and complete for simple people without any medical expertise.

\section{Excerpt from the volume. Formula 1:}

Hikiä ajawa Tincturi eli öljy. Ota Walerianan (Ruton juuren) juurta ja putken juurta (Angelika) kumpiain 1 luodi, Liwerstikan juurta 1/2 luodi, leikkaa hienoxi, sekoita; lyö Palowijnaa päälle, sido kalwolla, pane lämpymään poroon, wetäymään, sijwihte 
ja pane tallelle. Ota 20 eli 40 tippua - ajaa hikeen ja weren lijkkumaan. On myös matoja ja rewäsintä wasten.

\section{In today's Finnish:}

Hiostava tinktuura eli öljy. Ota Valerianan (Ruttojuuren) juurta ja putken juurta (Angelika) kumpaakin 1 luoti, liverstikan juurta 1/2 luotia, leikkaa hienoksi, sekoita, laita paloviinaa päälle, sido kalvoilla, pane lämpimään poroon, vetäytymään, suodata ja pane talteen. Ota 20 tai 40 tippaa - hiostaa ja stimuloi verenkiertoa. Sopii myös matoja ja vatsatautia vastaan.

\section{English translation:}

"Sweat tincture or oil. Take some valerian (butterbur) and angelica root, a $\operatorname{lot}^{1}$ of each, and half a lot of lovage. Chop them up finely, mix them, pour some spirit on the mix, tie it up in a piece of thin leather, put it in hot ash until it shrinks, filter it and put it away. Use 20 or 40 drops a time - it makes you sweat and stimulates blood circulation. It is also good for worms and colic."

\section{Vocabulary in the medicine book}

The main text is in Finnish, but some Latin and Swedish expressions also occur in the vocabulary. The present study examines medical vocabulary in the book. Medical vocabulary is a collective name for the following: pharmaceutical ingredients; diseases and symptoms; technical tools and methods; adjectives for the description of the consistency or other quality attributes of the given medical preparation; and units of measurement.

\section{Latin expressions}

The Latin words of the text are usually names of ingredients. They mostly refer to components that were only available in pharmacies at the time: various types of minerals, resins, and plant parts not available in nature in Finland, e.g.:

No. 4: Ota 1 naula Waxia, (...) ja 4 luodia Storax Calamita 'take a pound of wax (...) and four lots of resin' < Lat. storax 'resin', calamita 'residue'.

No. 5: ja 2 luodia Myrrha, molemmat hienoxi jauhoxi surwotut 'take two lots of myrrh, both of them ground to fine powder' < Lat. myrrha 'myrrh'.

No. 11: Camforti Spiritus, ei ole muuta kuin Camfortti sulattu Palowijnasa hywin äkeäxi 'camphor spirit is camphor dissolved in

\footnotetext{
${ }^{1}$ Translator's note: old unit of weight in many European countries, which equals about 13-14 grams.
} 
spirit in a big concentration' < Lat. camphorum 'camphor', spiritus 'alcohol'.

In the case of ingredients only available in pharmacies, the Latin name remained unchanged as a loanword. The main reason for this was probably the fact that pharmacists knew these expressions and translation was not necessary.

As far as indigenous species of herbs are concerned, the Latin name was sometimes used to complement the Finnish name, in brackets. This was probably intended to make the identification of the ingredient easier. E.g.:

No. 19: Oxennus juurta (ipekacuanha) 'ipecac (Ipecacuanha)'.

In some places, the Latin name is primary and the Finnish name is given only for the sake of clarification:

No. 4: Ota 1 naula Waxia, ja saman werta Colophoniumia eli Hartsia 'take a pound of wax and the same amount of resin'.

It is perfectly reasonable to use multiple names at the same time for the identification of a certain plant, because in the case of collecting herbs from the natural environment, it was very important to be able to recognize similar but poisonous or useless plants compared to the one needed for a given medicine. Still, there are instances in the book where the names given for an herb as synonymous in fact refer to two different plants. This is the case with waleriana 'valerian' (Fi. rohtovirmajuuri), where the bracketed expression for "clarification" refers to the plant called butterbur (Lat. Petasites, Fi. ruttojuuri).

No. 1: Ota Walerianan (Ruton juuren) juurta 'Take some valerian (butterbur) root'.

The explanation lies in the fact that folk healers did not necessarily differentiate between different species of herbs, they often used a collective name for certain medicinal plant parts. For example, a name like 'laxative root' could refer to a number of plants that had the same effect, or of which the same part was used as medicine. Thus, it could happen that the healer used different kinds of roots mixed together as if they had been one single plant.

The names of drugs and some of the materials necessary for their preparation are also used in Latin, e.g.:

Preface: Lääkitysten, Metikamentein ja Woidetten nimeä 'the names of medicine, drugs and ointments' < Lat. medicamentum 'drug, medicine' (the Latin loan is already suffixed in Finnish here, in the genitive plural). 
No. 1: Hikiä ajawa Tincturi eli öljy 'Sweat tincture or oil' < Lat. tinctura 'alcoholic solution'. This form is also partly Finnicized, ending in an $-i$, characteristic of loanwords in Finnish.

No. 11: on tämä Spiritus hywä saipuan kansa 'this spirit is good for that, applied together with soap' < Lat. spiritus 'spirit, alcohol'.

No. 16: Että tehdä Essentia Witae (Elämän öljyä) ja mihenkä se kelpaa ja on hywä 'preparation of the water of life, what it is favorable and good for' < Lat. essentia vitae 'elixir of life'.

Apparently, Latin expressions refer to ingredients or technical information that could be useful first and foremost for a professional preparing the drug. Therefore, these words are used in the text without (or with only minimal) modification (Finnicization). Body parts or symptoms, however, are never referred to in Latin, because Finnish readers would not have been able to understand the formula then.

Ganander left the spelling of Latin words essentially unchanged. The intended audience did not understand Latin, and those few who did (doctors and pharmacists) were able to read the formula with the original spelling as well. However, it is interesting that certain words in formulae collected from various territories often differ in spelling, e.g. camphoratus 'camphor' is the original Latin form, but the variants camfortti, comfortti, camfertti, camforti are Finnicized to a certain extent. The fully Latin spelling is more characteristic of formulae that the author adopted from other books of medicine, while the other variants were probably collected and used on the basis of the dialect of the given area.

\section{Swedish loan elements}

The book contains a number of Swedish loan elements as well. It is hard to assess whether these were still foreign elements at the time of collection in the areas visited by Ganander or had already been integrated into the language as loans. The majority of Swedish words in the text are ingredients and particularly herbs or parts of plants:

No. 2: ota Waxia, ja Suutarin pikiä 'take some wax and cobbler's pitch' < Sw. vax 'wax'.

No. 33: ota keltaisia Reenfanan ja Camillin kukkia, warsista nykityt 'take some tansy and chamomile flowers, plucked from the plant' $<$ Sw. renfana 'tansy'.

No. 17: Malin-nuppia ja Lawendeli-kukkia, kourallinen kumpiain, hakataan hienoxi 'chop a handful of wormwood buds and a handful of lavender flowers finely' < Sw. lavendel 'lavender'.

No. 5: ja 2 luodia walkiata Lilje-öljyä, ja wihdoin 3 luodia (muutamalla palowijna pisaralla) hienoxi jauhettua Camforttia '2 lots of lily oil 
and 3 lots of powdered camphor (mixed with some drops of distilled spirits)' < Sw. lilja 'lily'.

The author frequently provides us with the names of herbs in more than one language and sometimes uses both Swedish and Finnish names for the same plant within the same formula:

No. 7: pakkaa Wanhoja Tuohia ja Newa kanerwia (get pors) isompaan pataan 'put some old birch bark and heather (ling) in a larger bowl' < Sw. getpors 'heather' (literally: 'goat + shrub').

This method had probably been intended to make the identification of the given herb easier. However, in some cases, it turned out to be counterproductive: the bracketed name does not always refer to the same plant as the main expression (as it is the case with the Latin names as well).

It seems probable that after finishing his collecting work, Ganander did not consolidate the various names for the same herb. Thus, if the informant used only a Swedish word for a plant, the Finnish counterpart was not put down next to it, but if the speaker used both Swedish and Finnish expressions, the author recorded both.

Another large group of Swedish-origin words are expressions referring to utensils and methods for preparing drugs, and other words describing certain qualities of a medicine (type, color, time period, and consistency):

No. 30: on kuumentawa lääkitys, pruukataan ainoastans nijlle, joilla on kinonen ja kylmä ruumis 'warming medicine applied if one's body is stiff or cold'. The pruukata form first occurred in Agricola's work. Its precedent was Sw. bruka 'to use, to apply' (SSA 2: 413).

No. 16: yhteen korttelijn Franskt (...) wijnan sekaan 'mixed with one kortteli ${ }^{2}$ of French spirit' < Sw. fransk 'French'; the neuter gender form is franskt, which clearly shows that it is still the Swedish word that is used here (SSA 3: 47). (The kortteli is a unit of volume, onequarter of a pint.)

No. 15: sixi kuin se tulee klaarixi 'until it is clean'. The first written occurrence of klaari in Finnish is from 1638, and from 1731 as a verb (klaarata). It is an adoption of the Swedish adjective klar 'bright, clear' (cf. Lat. clarus) (SSA 1: 378).

\footnotetext{
${ }^{2}$ Translator's note: old Finnish unit of measurement that equals about $330 \mathrm{ml}$.
} 
No. 7: ja se reikä kansi wäliin, sawella klijsteröity, tee walkia päälle '[and insert] the punctured cover plate, seal it with clay and make a fire on it' $<$ Sw. klister 'glue', klistra 'to glue'.

No. 3: klasi kaataan sitten täyteen wettä 'fill the bottle with water'. Agricola used the form clasi. Today's Finnish form is lasi. It is a Swedish loan, cf. Sw. glas 'bottle, glass' (SSA 2: 49).

No. 4: sixi kuin se tulee pruunixi 'until it turns brown' $<$ Sw. brun 'brown'.

Apparently, these Swedish loanwords were adopted in everyday language as well, not only in the language of medicine. Ganander probably collected the formulae containing these in areas of strong Swedish influence.

Certain diseases and symptoms are given in Swedish as well, in brackets, for the sake of disambiguation, e.g.:

No. 15: Lasten nawan puhkemiseen itkusta (bråck) 'When a child's abdominal wall ruptures from crying (hernia)' < Sw. brock 'hernia'.

No. 18: Jolla on (...) ja jalka-tauti (podager) 'those who have a foot disease (podagra, gout)' $<$ Sw. podager < Lat. podagra 'gout'.

It is generally true of the Swedish expressions occurring in the formulae that the author tried to use a way of spelling that is as close to Finnish as possible. E.g. the characteristically Swedish $b$ and $g$ sounds are usually substituted with $p$ and $k$ (bruka $>$ pruukata, brun > pruun; glas > klasi), and words are affixed in Finnish. All of this shows that these Swedish loans had already been integrated (or were in the process of integration) into Finnish language in the region where Ganander collected this material (cf. Juhos 2019: 109-115).

\section{Spelling}

Ganander's orthography is rather inconsistent. One of the reasons may be that formulae collected from various places and from a number of different written sources applied different ways of spelling for the same word. Also, variation may result from the fact that the informants spoke several different dialects. Today's standard $-t s$ sound combination for example is also marked with the dialectal - $h t$ - (sijwihte = siivitse 'to filter', paihti $=$ paitsi 'except') and -tt- (watta = vatsa 'abdomen, belly') in the book. In any case, Ganander did not check and consolidate the spelling of the finished book.

It is a clear development in Ganander's way of spelling compared to Agricola, that the $\ddot{a}$ and $e$ sounds show an almost completely regular pattern. Latinized forms are still frequent in his work as well, including letters that are not used in Finnish. This 
demonstrates that although Ganander lived and worked almost two hundred years after Agricola, certain sounds and especially sound combinations still did not have a fixed written representation.

Sometimes, Ganander uses the voiced counterpart to mark voiceless stops: luodi (in today's Finnish: luoti 'lot [measurement]'), tygö (tykö 'to [suffix]'). After nasals, he sometimes uses $d$ and $g$, although very rarely: pandu (pantu 'put [past tense, 3rd person singular]'), jonga (jonka 'who [relative pronoun]'), kuitengin (kuitenkin 'still, however'). But: kypsentää 'to become ripe, to mature', monta 'a lot of', parantaa 'to heal', henkiwedon (henkiveto 'breath'), johonka 'to somewhere'. The mb letter combination does not occur anywhere, only mp: isompaan (< isompi 'larger'), kumpiaan (< kumpi 'which'), pienempi 'smaller', suurempi 'larger', ympäri 'around'.

Similarly to many others before, he always and consistently marks the $k s$ sound combination with $x$ : yxi (yksi 'one'), kaxi (kaksi 'two'); jauhoxi (jauhoksi < jauho 'flour'), hienoxi (hienoksi < hieno 'fine, tiny'), kowaxi (kovaksi < kova 'hard'), päiväxi (päiväksi < päivä 'day'), pienexi (pieneksi < pieni 'small, little') etc.

The sound $v$ is only once marked with $v$ in the corpus examined (päivä 'day'), and in every other case it is marked with $w$, e.g. ajawa (ajava 'to lead, to carry'), arwet (arvet 'scars'), haawa (haava 'wound'), hywä (hyvä 'good'), päiwä (päivä 'day'), kanerwia (kanervia < kanerva 'heather'), kowaxi (kovaksi < kova 'hard'), nawan (navan < napa 'navel') etc.

The long $i$ (ii) is usually marked with $i j$, e.g. lijna (liina 'fabric'), tijma (tiima 'hour'), nijn (niin 'this way'), sijhen (siihen 'there'), sijtä (sitä 'that'), wiinaa (viina 'vodka, spirit'), but rarely the niin 'like that', siihen 'there', wiina 'vodka' forms are used as well (cf. Juhos 2018: 92-94).

\section{Morphological issues}

The inessive case is very regular in Ganander's work: in one- or two-syllable roots it is -sa, e.g. josa (in today's standard Finnish: jossa < joka 'something'), kiehuesa (kiehuessa < kiehua 'to boil'), taudisa (taudissa < tauti 'disease'), kuumisa (kuumiissa $<$ kuuma 'hot'), wedesä (vedessä < vesi 'water'); in longer roots it is -s: ihmisis (ihmisissä < ihminen 'person, man'), hewoisis (hevoisissa < hevonen 'horse').

The illative case is marked as follows: astiaan (< astia 'vessel, bowl'), isompaan (< isompi 'larger'), kattilaan (< kattila 'pot'). Ganander uses both the $i j$ and $i i$ letter combinations in illative forms: kaikkijn (kaikkiin 'to/for everything'), kellarijn (kellariin 'to the cellar'), klasijn (lasiin 'to a bottle, to a glass'), tautijn (tautiin 'into a disease') - kaikkiin, kuppiin (< kuppi 'cup'), muottiin (< muotti 'shape'), paperiin (< paperi 'paper'), selkiin (< selkä 'back'), tautiin (< tauti 'disease, ailment'). 
Genitive plural: jalkain, marjain, patain. There is some variation in today's Finnish as well: next to the jalkojen, marjojen, patojen forms, the variants used by Ganander exist as well (jalka 'foot, leg', marja 'berry', pata 'pot').

\section{Summary}

In Ganander's time, the book titled Maan-Miehen Huone- ja Koti-Aptheeki filled a void long present, since this was the first Finnish language book of medical subject matter. The fact, however, that the book was to be published in Finnish, made it necessary to create medical vocabulary understandable to the Finnish lay person, as a significant part of the medical language was in Swedish and Latin earlier. The base text of the book is Finnish, complemented with some Latin and Swedish origin expressions.

The Latin elements usually refer to resins, minerals and chemicals only available in pharmacies, and also plant parts not accessible in nature in Finland. The author did not find it necessary to translate or Finnicize these expressions, because pharmacists knew this vocabulary anyway.

In the case of Swedish loan elements, it is not certain whether the given expression was still a loan or had completely integrated into everyday Finnish language at the time of collection. It is characteristic of these words that they do not necessarily belong to the vocabulary of medicine and can refer to general attributes like consistency or color. Swedish elements are usually Finnicized in the text, both from the point of sound and letter correspondences and affixation. This also indicates that these loanwords were probably integrated into the Finnish language at the time. It is especially frequent in the case of plant names where only the Swedish name is given, which makes it probable that the informant knew only this one name for the herb. In contrast, body parts and general symptoms (e.g. pain, fever) are all in Finnish.

Spelling cannot be considered as standard and established in the book. This can be attributed to the different places of birth and dialects of the informants and also to the influence of Latin on the orthography of the time. Ganander did not consolidate the use of spelling or the names recorded in several different variants.

Ganander's book represents an important milestone in the development of Finnish medicine. With the detailed listing of the ingredients and the simple and clear way of phrasing, his goal was to enable simple Finnish people to use these healing practices and to facilitate that the collected formulae reach as wide an audience as possible.

\section{References}

Forsius, Arno 1995. Lääkärit apteekkareina. Suomen Lääkärilehti, 33: 3638. 
Forsius, Arno 2005. Kuolinsyyt vuosien 1749-1877 väkilukutauluissa. In: Epidemioista, väestötapahtumista ja kuolinsyistä. Suomen sukututkimusseuran julkaisuja 40: 81-97. Pieksämäki.

Ganander, Kristfrid 1788. Maan-Miehen Huone- ja Koti-Aptheeki. Rantsila.

Gustaffson, Philip 1995. Kristfrid Ganander - 1700-luvun monipuolinen valistusmies. In: Pentikäinen 1995: 203-219.

Haarala, Risto 1999. Miten lääketieteen suomea huolletaan? Kielikello 1999/3. https://www.kielikello.fi/ /miten-laaketieteen-suomea-huolletaan

Häkkinen, Kaisa 1995. Kristfrid Ganander etymologina ja leksikografina. In: Pentikäinen 1995: 161-180.

Harjula, Minna 2007. Terveyden jäljillä. Suomalainen terveyspolitiikka 1900-luvulla. Tampere: Tampere University Press.

Ignatius, Jaakko 2000. Lääketieteet. In: Tommila, Päiviö (toim.), Suomen tieteen historia 3. Helsinki: Luonnontieteet, lääketieteet ja tekniset tieteet. WSOY.

Juhos, Meri 2018. Kristfrid Ganander orvosságoskönyve (1788) [Kristfrid Ganander's Medical Guide (1788)]. Folia Uralica Debreceniensia, 25: 73-98.

Juhos, Meri 2019. Jövevényelemek Kristfrid Ganander orvosi nyelvezetében [Loan elements in Kristfrid Ganander's medical terminology]. Folia Uralica Debreceniensia, 26: 107-122.

Lääkäriliitto 2008. Lääkärien määrän kehitys vuosina 1900-2008. http://www.laakariliitto.fi/tilastot/laakaritilastot/kehitys.html

Pentikäinen, Juha (toim.) 1995. Kristfrid Ganander, Mythologia Fennica. Suomalainen Mytologia. Tampere: Recallmed Oy.

Pentikäinen, Juha 1995a. Kristfrid Ganander mytologina. In: Pentikäinen 1995: 133 160.

Pesonen, Niilo 1973. Lääkärinä ja virkamiehenä. Lääkintöhallituksen pääjohtaja muistelee. Helsinki: WSOY.

SSA = Itkonen, Erkki and Kulonen, Ulla-Maija (toim.): Suomen sanojen alkuperä 13. Helsinki: Suomalaisen Kirjallisuuden Seura, 1992-2000. 